University of Nebraska - Lincoln

DigitalCommons@University of Nebraska - Lincoln

September 2004

\title{
PEDOGENIC FACTORS AFFECTING MAGNETIC SUSCEPTIBILITY OF THE LAST INTERGLACIAL PALAEOSOL S1 IN THE CHINESE LOESS PLATEAU
}

\author{
Z.-D. Feng \\ Montclair State University \\ H. B. Wang \\ National Laboratory of Western China's Environmental Systems, MOE, Lanzhou University, Lanzhou, \\ Gansu 730000 China \\ C. G. Olson \\ USDA, NRCS, National Soil Survey Center, 100 Centennial Mall North, Lincoln, Nebraska
}

Follow this and additional works at: https://digitalcommons.unl.edu/usdaarsfacpub

Part of the Agricultural Science Commons

Feng, Z.-D.; Wang, H. B.; and Olson, C. G., "PEDOGENIC FACTORS AFFECTING MAGNETIC SUSCEPTIBILITY OF THE LAST INTERGLACIAL PALAEOSOL S1 IN THE CHINESE LOESS PLATEAU" (2004). Publications from USDA-ARS / UNL Faculty. 210.

https://digitalcommons.unl.edu/usdaarsfacpub/210

This Article is brought to you for free and open access by the U.S. Department of Agriculture: Agricultural Research Service, Lincoln, Nebraska at DigitalCommons@University of Nebraska - Lincoln. It has been accepted for inclusion in Publications from USDA-ARS / UNL Faculty by an authorized administrator of DigitalCommons@University of Nebraska - Lincoln. 


\title{
PEDOGENIC FACTORS AFFECTING MAGNETIC SUSCEPTIBILITY OF THE LAST INTERGLACIAL PALAEOSOL S1 IN THE CHINESE LOESS PLATEAU
}

\author{
Z.-D. FENG ${ }^{1,2, *}$, H. B. WANG ${ }^{1}$ AND C. G. OLSON ${ }^{3}$ \\ ${ }^{\prime}$ National Laboratory of Western China's Environmental Systems, MOE, Lanzhou University, Lanzhou, Gansu 730000 China \\ ${ }^{2}$ Department of Earth and Environmental Studies, Montclair State University, Upper Montclair, New Jersey 07043, USA \\ ${ }^{3}$ USDA, NRCS, National Soil Survey Center, 100 Centennial Mall North, Lincoln, Nebraska 68508, USA
}

Received 10 March 2003; Revised 22 March 2004; Accepted 20 April 2004

\begin{abstract}
The magnetic susceptibility has been used as a quantitative or semi-quantitative proxy for reconstructing the summer monsoon intensity in the Chinese Loess Plateau based on extensive studies on climatic or/and environmental mechanisms producing the magnetic susceptibility signatures. However, the precise nature of the link between past climates and the susceptibility signatures has remained uncertain primarily due to lack of our understanding in the finalizing and preserving processes of the signatures. This paper attempts to examine the reliability or acceptability of this summer monsoon proxy from non-magnetic perspectives of soil-forming processes. We chose nine sections along two transects: one across the western part of the Chinese Loess Plateau and another across the eastern part. Several conclusions can be drawn from our analytical data. First, clay translocation within the S1 palaeosol profiles, as indicated by field-observed clay coatings on ped faces in $\mathrm{Bt}$ and $\mathrm{Bk}$ horizons and demonstrated by laboratory-analysed clay contents, must have moved some of the magnetic minerals downward so that the susceptibility reflects only the post-translocation distribution of the magnetic-susceptibilityproducing minerals. Second, the best-developed palaeosol S1S3 at most of the sections studied is not expressed by the magnetic susceptibility because this palaeosol developed in underlying coarse loess (L2) and coarse textures tend to lower the susceptibility. Third, carbonate concentration is normally negatively correlated with the magnetic susceptibility or simply suppresses the magnetic susceptibility peak when the susceptibility enhancement exceeds the carbonate dilution effect. To conclude, extreme caution must be observed when using magnetic susceptibility signatures to retrieve high-resolution records of the last interglacial palaeoclimate in the Chinese Loess Plateau. Copyright @ 2004 John Wiley \& Sons, Ltd.
\end{abstract}

KEY WORDS: last interglacial; palaeosols; magnetic susceptibility; palaeoclimate

\section{INTRODUCTION}

Various magnetic parameters have been employed to demonstrate the degree of pedogenesis within loess, and they have commonly been used as palaeoclimatic proxies in the Chinese Loess Plateau. The magnetic susceptibility signature in Chinese loess, which was the first to show a close correlation with the oceanic $\delta^{18} \mathrm{O}$ signature (Kukla et al., 1988), remains the most convincing climatic proxy (Derbyshire et al., 1997; Heller and Evans, 1995; Maher, 1998; Zhang and Chen, 1995). The susceptibility has therefore been used extensively as a semi-quantitative proxy for reconstructing the summer monsoon intensity (Kukla et al., 1988; An et al., 1991a, b; Kukla et al., 1990; Sun et al., 1995; Chen et al., 1997; Fang et al., 1999) as well as a quantitative proxy for reconstructing mean annual precipitation (Sun et al., 1995; Heller et al., 1993; Maher and Thompson, 1995; Maher et al., 1994). However, the precise nature of the link between past climates and the susceptibility has remained uncertain.

\section{Three distinctive proposals for the magnetic susceptibility signature}

Three distinctive hypotheses have been proposed to explain the link between the magnetic susceptibility and climate. First, it was proposed that the magnetic influx has remained constant, with the intensity of dustfall modulating the variation in the susceptibility (Kukla et al., 1988, 1990; An et al., 1991a, b). The second

* Correspondence to: Z.-D. Feng, Department of Earth and Environmental Studies, Montclair State University, Upper Montclair, New Jersey 07043, USA. E-mail: fengz@mail.montclair.edu 
hypothesis states that the degree of pedogenesis has controlled the variation in the susceptibility (Maher and Thompson, 1991, 1992, 1995; Zhou et al., 1990). The third proposal states that the susceptibility signature is a combined result of pedogenic enhancement and detrital inheritance (Fine et al., 1993, 1995; Verosub et al., 1993; Zheng et al., 1991).

Feng (1996) argued that the annual magnetic susceptibility would have to have been constant through time if the first proposal holds. He then calculated the annual susceptibility $M S_{\text {annual }}$ as:

$$
M S_{\text {annual }}=(V S \times H) / T
$$

where $V S=$ volumetric susceptibility, $H=$ thickness, and $T=$ time span. The calculated results showed that the annual susceptibility of the last interglacial palaeosol S1 is less than half that of the last glacial loess L1 in the northwestern part of the Chinese Loess Plateau where post-depositional alteration has been minimal, and thus the constant magnetic influx proposal does not pass the test. To test the second proposal, Feng (1996) demonstrated that the annual susceptibilities of both the last interglacial palaeosol S1 and the last glacial loess L1 do not exhibit a southeasterly increasing trend, although the second proposal predicts such a trend. The third proposal seems reasonable, but it does not include other pedogenic factors that do not necessarily enhance the magnetic susceptibility signature. The pedogenic factors primarily refer to three in situ processes that produce susceptibility-enhancing minerals. They are (1) low-temperature oxidation, (2) geochemical alteration, and (3) biogenic formation (Banerjee et al., 1993; Cui et al., 1994; Derbyshire et al., 1995, 1997, 1998; Evans and Heller, 1994, 2001; Evans and Rokosh, 2000; Eyre and Shaw, 1994; Heller and Evans, 1995; Heller et al., 1993; Liu, 2000; Liu and Liu, 1993; Liu et al., 1992, 1995, 1999; Maher, 1998, 1999; Maher and Thompson, 1991, 1992, 1995, 2000; Meng et al., 1997, 1999; Mullins, 1977; Sun and Liu, 2000; Zhou et al., 1990).

\section{Two components of the magnetic susceptibility signature}

Based on stratigraphic comparison of the magnetic susceptibility (Kukla et al., 1988) and ${ }^{10} \mathrm{Be}$ flux (Shen et al., 1992) at the Luochuan section (see Figure 1 for locations), Beer et al. (1993) and Heller et al. (1993) concluded that 45-75 per cent of the magnetic susceptibility signature is pedogenic in palaeosols and only about 20 per cent in loess units. The remainder is the dust component. Evans and Heller (1994) demonstrated that the isothermal remanence magnetization (IRM) spectra remain identical from the northwest to the southeast on the Chinese Loess Plateau, suggesting that a uniform magnetic component-A is widespread across the plateau. Subtracting component-A from the total isolates component-B which increases southeastward, reflecting the summer monsoon pattern. Component-A is inherited from parent materials and component-B is pedogenic. This two-component proposal is in good agreement with the work by Banerjee et al. (1993) and was reconfirmed by Evans and Heller (2001). Fine et al. (1995) and Verosub et al. (1993) used the citrate-bicarbonate-dithionite (CBD) method to distinguish the pedogenically derived susceptibility signature from the parent materialinherited signature. However, Liu et al. (1995) have proved that the CBD method is inadequate in separating these two types of signatures.

\section{Other factors affecting the magnetic susceptibility signature}

Dilution by carbonate concentration (Heller and Liu, 1986), magnetic enhancement by leaching processes (Anderson and Hallet, 1996), and magnetic alterations by redox cycles (Feng et al., 1994a, b, c, 1998; Feng and Chen, 1999; Feng and Johnson, 1995; Li et al., 1996; Liu, 2000; Liu et al., 1999; Sun and Liu, 2000; Virina et al., 2000; William, 1992) and even particle-size redistribution (Feng, 1997; Feng and Johnson, 1995; Han and Jiang, 1999; Wang et al., 1996; Zheng et al., 1991) are soil-forming processes that contribute to the finalization of the susceptibility signature. Each of the mentioned factors may be location-dependent and/or time-dependent. For example, Feng et al. (1998) showed that a reducing index and a leaching index are the two factors primarily modulating the variations in the magnetic susceptibility at the Beiyuan section in the Linxia Basin of western China, whereas the reducing index and particle size are the two factors primarily modulating the variations in the susceptibility of the northern Mongolian Plateau (Feng, 2001). In the Great Plains of the United States, variations in the susceptibility of the last glacial/interglacial loess-soil sequence are primarily controlled by three factors (Feng, 1997): particle size, carbonate concentration and an oxidizing index. In both the Great Plains of 

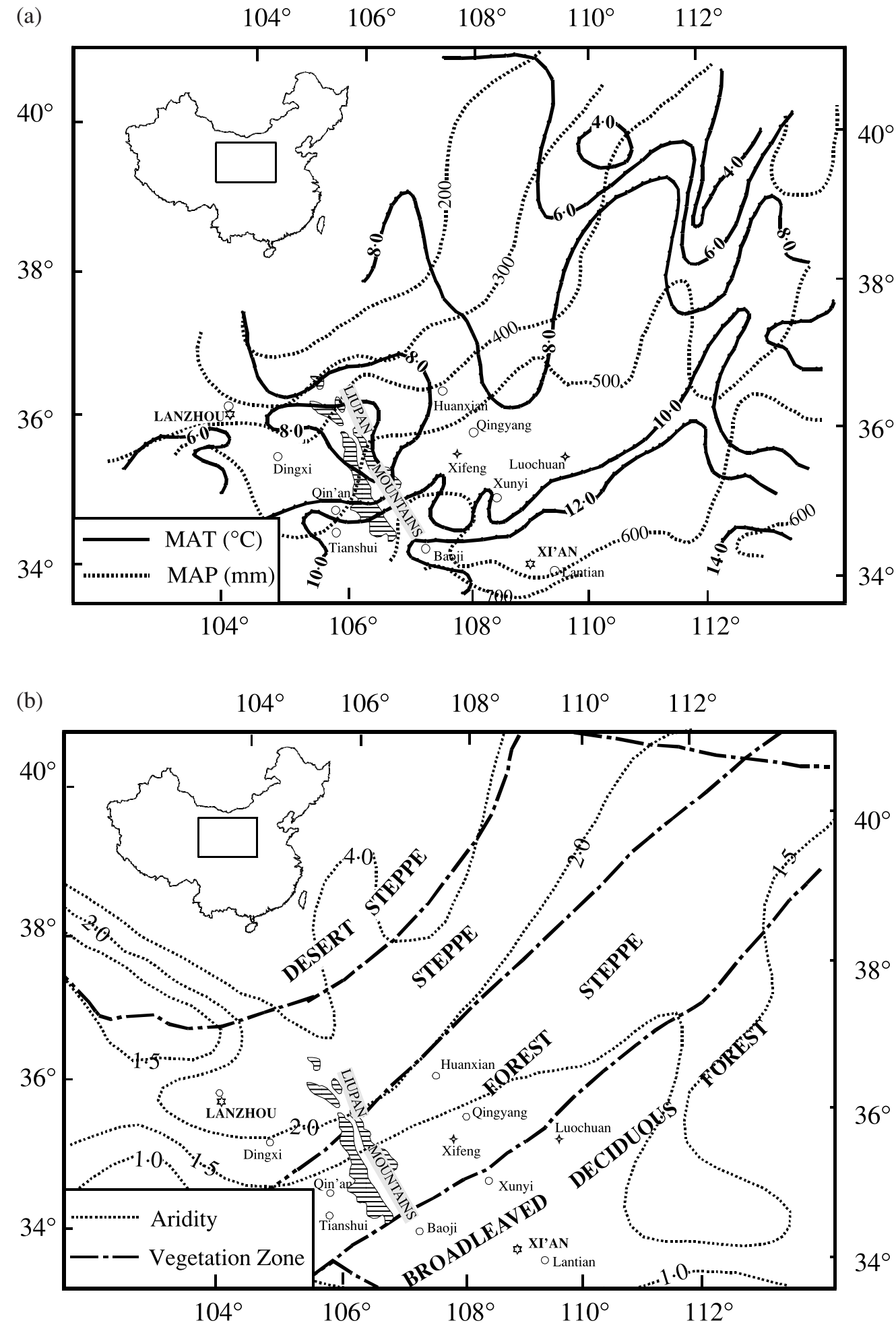

Figure 1. (a) Mean annual temperature (MAT) and mean annual precipitation (MAP) in the Chinese Loess Plateau. (b) Aridity and natural vegetation distributions in the Chinese Loess Plateau 
the United States and the Linxia Basin of western China, the variations in the susceptibility of the palaeosol formed during the marine oxygen isotope stage 5 are primarily controlled by the carbonate concentration and oxidizing index, whereas the variations in the magnetic susceptibility of the unit formed during the marine isotope stage 3 in both places are basically controlled by the reducing index (Feng et al., 1998; Feng, 1997). It is worth mentioning here that soil-forming processes under persistent or occasional water-saturated conditions normally lower the magnetic susceptibility signature (Evans and Heller, 2001; Feng, 2001; Feng et al., 1994a, b, c, 1998; Feng and Chen, 1999; Liu et al., 1999; Sun and Liu, 2000; Virina et al., 2000). In conclusion, the susceptibility lows and highs might be the result of a combination of pedogenic factors, and the relations of these factors to the summer monsoon intensity are by no means easy to determine.

\section{FIELDWORK STRATEGIES AND LABORATORY METHODS}

Because of the interaction between the winter and summer monsoons, there is an apparent SE-NW modern climatic gradient on the Chinese Loess Plateau (Li et al., 1988). That is, the mean annual precipitation (MAP) decreases gradually from the southeastern to the northwestern margins with the mean annual temperature (MAT) increasing southward (Figure 1a), whereas the aridity (the ratio of evaporation and precipitation) increases gradually toward the northwest. The vegetation closely follows the aridity trend (Figure 1b). The Liupan Mountains divide the Loess Plateau into eastern and western parts.

In order to investigate the geographic differentiation of the last interglacial palaeosol S1 and its climatic significance, we chose two transects (see Figures 1a and b): one across the eastern part of the Loess Plateau from Huanxian to Lantian near Xi' an, and another across the western part from Lanzhou to Tianshui extending to Lantian. The S1 palaeosol profiles of the nine sections chosen on the two transects were first described in the field based on the characteristics of the soil horizons (Birkeland, 1999; Buol et al., 1989; Catt, 1986, 1990; Foth, 1978) and then sampled at 2-cm intervals for laboratory analyses. At all sections investigated, sampling began in the basal part of the L1 loess unit that overlies the S1 palaeosol and ended in the uppermost part of the L2 loess that underlies the S1 palaeosol. The magnetic susceptibility (SI) was measured by the procedure of Thompson and Oldfield (1986) using a Bartington MS 2B susceptibility meter, and the frequency-dependent susceptibility was calculated based on the high- and low-frequency susceptibility measurements. The particle size of bulk samples was measured using a Malvern Co. Ltd Mastersizer 2000 laser diffraction particle size analyser (Chen et al., 1997) and pretreatments of the samples for particle size analysis include adding (1) $\mathrm{H}_{2} \mathrm{O}_{2}$ to remove organic and soluble salts, (2) diluted $6 \mathrm{NHCl}$ to remove carbonate, and (3) Na-hexametaphosphate to disperse the aggregates (Janitzky, 1987). The carbonate content was measured with the modified gas evolution method (Machette, 1986) using the Bascomb Calcimeter.

\section{GEOGRAPHIC VARIATIONS OF THE SUSCEPTIBILITY SIGNATURE}

The net accumulation of loess should have attenuated and the pedogenesis should have intensified southeastward during the last interglacial. Consequently, the last interglacial palaeosol (S1) profiles and their relations to their parent materials should have systematically varied from the northwest to the southeast.

\section{Geographic differentiation of the pedostratigraphy}

In the northwestern part of the Loess Plateau (e.g. at the Lanzhou section in Figure 1), an $8 \mathrm{~m}$ thick S1 pedocomplex consists of multiple A-C soil profiles (Chen et al., 1999; Derbyshire et al., 1995, 1997; Kemp et al., 1995, 1997). Three incipient soils (A-C profiles) mark the marine isotope sub-stages 5a (S1S1), 5c (S1S2) and 5e (S1S3). Two interbedded loess units demarcate the sub-stages 5b (S1L1) and 5d (S1L2) (Figure 2). Southeastward near Dingxi where the $\mathrm{S} 1$ palaeosol is $5 \mathrm{~m}$ thick, two incipient soils (A-C profiles) corresponding to the marine isotope sub-stages $5 \mathrm{a}$ and $5 \mathrm{c}$ are better developed than those at the Lanzhou section. Corresponding to the sub-stage 5e (i.e. S1S3) is a Mollisol-like soil with both A horizon and Bk horizon developed. Farther to the southeast near Qinan where the $\mathrm{S} 1$ palaeosol complex is $4 \mathrm{~m}$ thick, there are three Mollisol-like soils, each having an A horizon and a Bk horizon, corresponding to the three odd-numbered marine isotope sub-stages (5a, $5 \mathrm{c}$ and $5 \mathrm{e}$ ). The S1L1 loess unit separates the S1S1 and S1S2 palaeosols and the loess unit S1L2 between the 


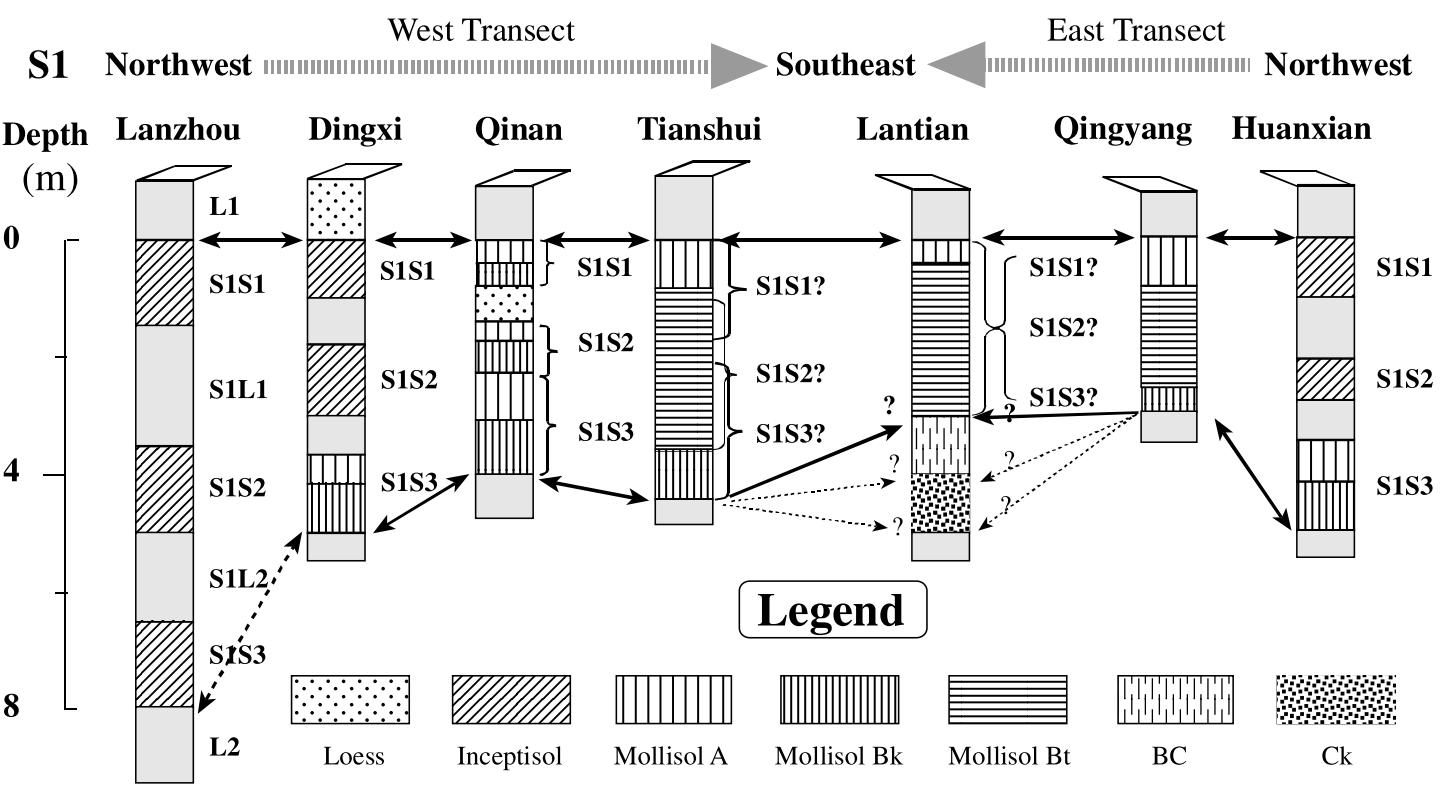

Figure 2. The geographic differentiation of the $\mathrm{S} 1$ palaeosol profiles from the northwestern margin to the southeastern margin in the Chinese Loess Plateau: all of the five pedostratigraphic units (S1S1, S1L1, S1S2, S1L2, S1S3) are preserved at the Lanzhou and Dingxi sections; the S1L2 was annexed by the S1S2 development at the Qinan section and both the S1L2 and S1L1 were annexed at the Tianshui sections; the $\mathrm{S} 1$ at the Lantian section is a completely welded palaeosol profile

S1S2 and S1S3 is not present here (see Figure 2). The S1 at the Tianshui section, about $50 \mathrm{~km}$ south of the Qinan section, is a pedocomplex without those two interbedded loess units, that is, neither S1L1 nor S1L2 is present. This $4.5 \mathrm{~m}$ thick $\mathrm{S} 1$ palaeosol has a $0.8 \mathrm{~m}$ thick mollic A horizon, a $2.5 \mathrm{~m}$ thick Bt horizon and $1.2 \mathrm{~m}$ thick Bk horizon.

Unlike the other sections reported here, the last glacial loess L1 (i.e. the Malan Loess) at the two sections selected in the Guanzhong Basin (Baoji and Lantian sections) is not loess. The loess units corresponding to the marine isotope stages (MIS) 2 and 4 experienced much stronger pedogenesis than the soil units S1S1 and S1S2 at the Lanzhou and Dingxi sections and the 'loess' unit corresponding to the MIS 3 has well-developed accretionary mollic A horizons (i.e. cumulic soils). The last interglacial palaeosol S1 is basically a well-developed Bt horizon. The Xunyi and Qingyang sections, located in the same bioclimatic settings as the well-known Luochuan and Xifeng sections in the eastern part of the Chinese Loess Plateau (Figure 1b), are characterized by a single soil profile with an A horizon, a Bt horizon and a Bk horizon. Carbonate coats the illuvial clay on ped-faces (threads and filaments) in the matrix of Bt horizons, and concentrates as masses or nodules in the Bk horizons at both sections. Farther to the northwest at the Huanxian section, the field-observed pedostratigraphy is similar to that at the Dingxi section and the laboratory-analysed data are similar to those at the Qinan section. Specifically, all three palaeosols (S1S1, S1S2 and S1S3) and the two intervening loess units (S1L1 and S1L2) are identifiable and the S1S3 palaeosol is the best developed (Figure 2).

To sum up, the last interglacial palaeosol (S1) profiles become gradually differentiated from the northwest to the southeast. Near the northwestern margin of the Loess Plateau, the three palaeosols (S1S1, S1S2, S1S3) corresponding to marine isotope sub-stages $5 \mathrm{a}, 5 \mathrm{c}$ and $5 \mathrm{e}$ and the two intervening loess units (S1L1 and S1L2) corresponding to marine isotope sub-stages $5 \mathrm{~b}$ and $5 \mathrm{~d}$ are completely preserved (e.g. at the Dingxi and Lanzhou sections). The three palaeosols (S1S1, S1S2, S1S3) are partially welded at the Tianshui section where accretionary B horizons dominate the S1 palaeosol profile, and the lower portion of the S1 palaeosol developed in the underlying older loess L2. During the same time interval (marine isotope stage 5), a single soil profile formed on the southeastern margin of the Loess Plateau (i.e. completely welded at the Lantian section) and a major portion of the S1 palaeosol developed into the underlying older loess L2. Consequently, the magnetic susceptibility 
should have responded to the geographic variations as already noted by some researchers (Derbyshire et al., 1995; Evans and Rokosh, 2000; Feng et al., 2004; Rokosh et al., 2002; Zhu et al., 2001).

\section{Geographic variations of the magnetic susceptibility signature}

Before examining the geochemical contributions (e.g. oxidizing, reducing and leaching indices) to the magnetic susceptibility signature, we had established that particle size distributions and carbonate concentrations account for the majority of the variations in the magnetic susceptibility signature. Yet, particle size distributions and carbonate concentrations in the S1 palaeosol profiles are the final results of pedogenic processes occurring during the entire soil-forming period. We first conducted a correlation analysis of the magnetic susceptibility signatures with seven particle size fractions and carbonate concentration for the nine chosen sections. We found that the following particle size fractions, as well as the carbonate concentrations, have the highest correlation coefficients with the magnetic signatures: $>63 \mu \mathrm{m}, 2-10 \mu \mathrm{m}$ and $<2 \mu \mathrm{m}$.

Lanzhou section. The following observations can be made from Table I and Figure 3. First, the low-field magnetic susceptibility $(\chi)$ does not negatively follow the overall trends of the percentage of $>63 \mu \mathrm{m}(r=$ $-0 \cdot 219, n=650)$ and its dictated median size $(M d)$. That is, the loess units within the S1 (S1L1 and S1L2) do not have higher magnetic susceptibility values than the L1 and L2, although the S1L1 and S1L2 are considerably finer. Second, the correlation between clay $(<2 \mu \mathrm{m})$ content and the magnetic susceptibility $(\chi)$ is very low $(r=0.056)$ and the correlation becomes negative in two zones: first at the depth of 8-9 m (marked as I in Figure 3) where higher clay contents correspond to lower magnetic susceptibility values, and second at the depth of 9-10 m (marked as II in Figure 3) where lower clay contents correspond to higher magnetic susceptibility values. Third, among all searched particle size fractions, the $10-2 \mu \mathrm{m}$ fraction has the highest correlation coefficient with the magnetic susceptibility $(r=0.421)$ and with the frequency-dependent susceptibility $(r=0.632)$. Fourth, the variations in the $>63 \mu \mathrm{m}$ and $10-2 \mu \mathrm{m}$ fraction account for the first-trend variations in the magnetic susceptibility. The second-trend variations superimposed on the first-trend ones are readily explained by the variations in the carbonate concentration. In general, the magnetic susceptibility highs are responsive to the carbonate lows $(r=-0.505)$ and the magnetic susceptibility lows within the magnetic susceptibility peaks expressing the S1S2 and S1S3 (marked as 1 and 2 in Figure 3) are responsive to the carbonate highs in particular.

Dingxi section. At the Dingxi section, the overall trend of the magnetic susceptibility from the L1 to the L2 through the $\mathrm{S} 1$ does not follow the particle size trends (both $M d$ and $>63 \mu \mathrm{m}$ fraction). That is, the loess units within the S1 (S1L1 and S1L2) do not have higher magnetic susceptibility than the L1 and L2 although the S1L1

Table I. The correlation coefficients of the magnetic susceptibility $(\chi)$ and frequency-dependent magnetic susceptibility $\left(\chi_{\mathrm{fd}}\right)$ with the percentages of particle size fractions and carbonate content at seven selected sections in the Chinese Loess Plateau

\begin{tabular}{|c|c|c|c|c|c|c|}
\hline Section & Variables & $>63 \mu \mathrm{m}$ & $10-2 \mu \mathrm{m}$ & $<2 \mu \mathrm{m}$ & $\mathrm{CaCO}_{3}$ & $\chi_{\mathrm{fd}}$ \\
\hline $\begin{array}{l}\text { Lanzhou } \\
(n=650)\end{array}$ & $\begin{array}{c}\chi \\
\chi_{\mathrm{fd}}\end{array}$ & $\begin{array}{l}-0.219 \\
-0.446\end{array}$ & $\begin{array}{l}0.421 \\
0.632\end{array}$ & $\begin{array}{l}0 \cdot 056 \\
0 \cdot 267\end{array}$ & $\begin{array}{l}-0.505 \\
-0.335\end{array}$ & $\begin{array}{c}0 \cdot 864 \\
-\end{array}$ \\
\hline $\begin{array}{l}\text { Dingxi } \\
(n=300)\end{array}$ & $\begin{array}{c}\chi \\
\chi_{\mathrm{fd}}\end{array}$ & $\begin{array}{l}-0.501 \\
-0.705\end{array}$ & $\begin{array}{l}0 \cdot 565 \\
0 \cdot 780\end{array}$ & $\begin{array}{l}0 \cdot 133 \\
0 \cdot 376\end{array}$ & $\begin{array}{r}-0 \cdot 114 \\
0 \cdot 012\end{array}$ & $\begin{array}{c}0 \cdot 887 \\
-\end{array}$ \\
\hline $\begin{array}{l}\text { Qinan } \\
(n=250)\end{array}$ & $\begin{array}{c}\chi \\
\chi_{\mathrm{fd}}\end{array}$ & $\begin{array}{l}-0 \cdot 824 \\
-0 \cdot 866\end{array}$ & $\begin{array}{l}0 \cdot 825 \\
0 \cdot 849\end{array}$ & $\begin{array}{l}0 \cdot 491 \\
0 \cdot 615\end{array}$ & $\begin{array}{r}-0.094 \\
0.126\end{array}$ & $\begin{array}{c}0.873 \\
-\end{array}$ \\
\hline $\begin{array}{l}\text { Tianshui } \\
(n=250)\end{array}$ & $\begin{array}{c}\chi \\
\chi_{\mathrm{fd}}\end{array}$ & $\begin{array}{l}-0.732 \\
-0.764\end{array}$ & $\begin{array}{l}0.727 \\
0.769\end{array}$ & $\begin{array}{l}0.627 \\
0.640\end{array}$ & $\begin{array}{l}-0.748 \\
-0.665\end{array}$ & $\begin{array}{c}0.948 \\
-\end{array}$ \\
\hline $\begin{array}{l}\text { Lantian } \\
(n=300)\end{array}$ & $\begin{array}{c}\chi \\
\chi_{\mathrm{fd}}\end{array}$ & $\begin{array}{l}-0 \cdot 886 \\
-0 \cdot 914\end{array}$ & $\begin{array}{l}0 \cdot 918 \\
0 \cdot 838\end{array}$ & $\begin{array}{l}0.793 \\
0.787\end{array}$ & $\begin{array}{l}0 \cdot 119 \\
0 \cdot 172\end{array}$ & $\begin{array}{c}0.834 \\
-\end{array}$ \\
\hline $\begin{array}{l}\text { Qingyang } \\
(n=200)\end{array}$ & $\begin{array}{c}\chi \\
\chi_{\mathrm{fd}}\end{array}$ & $\begin{array}{l}-0.838 \\
-0.899\end{array}$ & $\begin{array}{l}0.973 \\
0.967\end{array}$ & $\begin{array}{l}0 \cdot 955 \\
0 \cdot 948\end{array}$ & $\begin{array}{l}-0.933 \\
-0.943\end{array}$ & $\begin{array}{c}0.963 \\
-\end{array}$ \\
\hline $\begin{array}{l}\text { Huanxian } \\
(n=350)\end{array}$ & $\begin{array}{c}\chi \\
\chi_{\mathrm{fd}}\end{array}$ & $\begin{array}{l}-0.853 \\
-0.877\end{array}$ & $\begin{array}{l}0 \cdot 935 \\
0 \cdot 940\end{array}$ & $\begin{array}{l}0 \cdot 946 \\
0 \cdot 957\end{array}$ & $\begin{array}{l}-0.733 \\
-0.641\end{array}$ & $\begin{array}{c}0.924 \\
-\end{array}$ \\
\hline
\end{tabular}




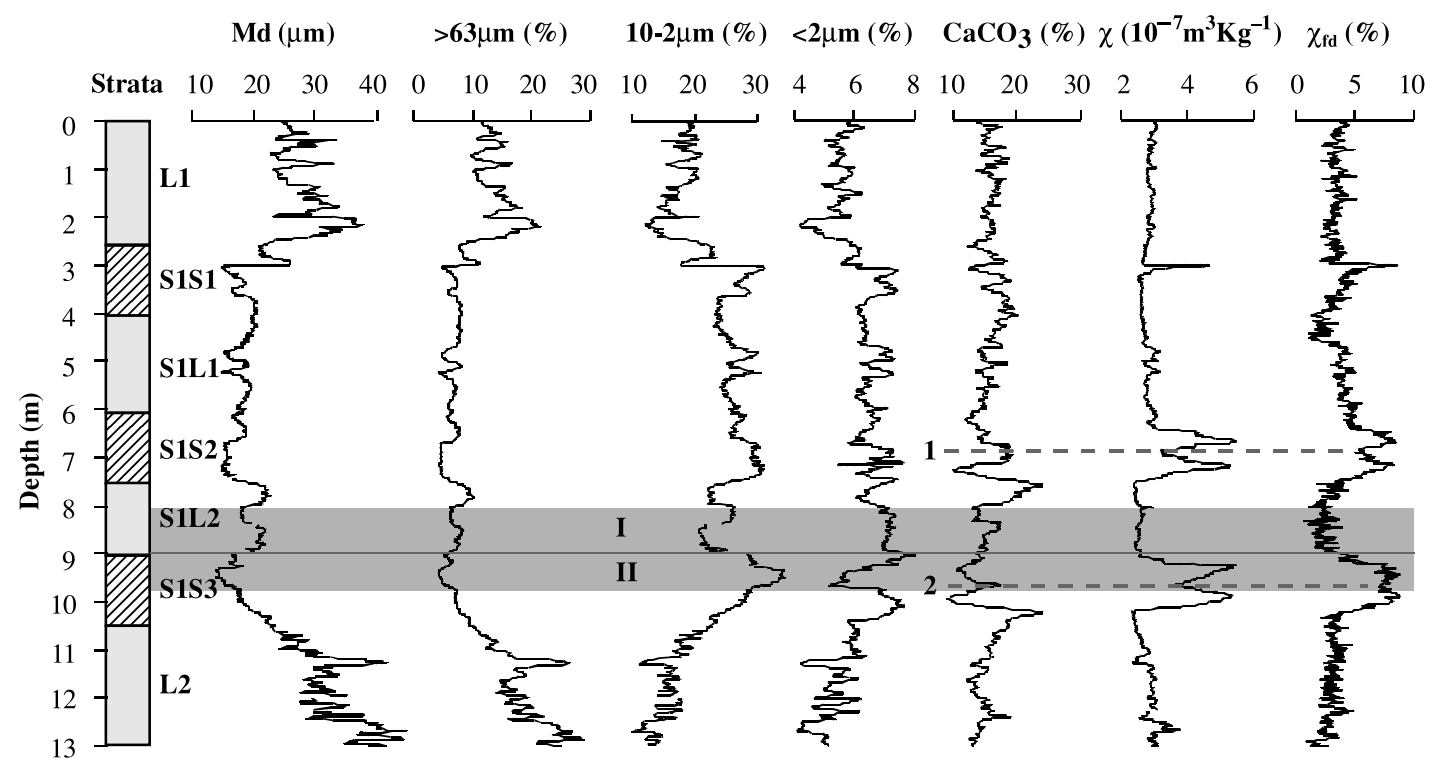

Figure 3. Lanzhou section: field-observed pedostratigraphy and laboratory data. Md $(\mu \mathrm{m})$, median size $(\mu \mathrm{m})$; $>63 \mu \mathrm{m}(\%)$, percentage of $>63 \mu \mathrm{m}$ fraction; $10-2 \mu \mathrm{m}(\%)$, percentage of $10-2 \mu \mathrm{m}$ fraction; $<2 \mu \mathrm{m}(\%)$, percentage of $<2 \mu \mathrm{m}$ fraction; $\mathrm{CaCO}_{3}(\%)$, percentage of carbonate; $\chi$, magnetic susceptibility $\left(10^{-7} \mathrm{~m}^{3} \mathrm{~kg}^{-1}\right)$ and $\chi_{\mathrm{fd}}$, frequency-dependent susceptibility $(\%)$

and S1L2 are considerably finer. The correlation coefficients of the susceptibility with $>63 \mu \mathrm{m}$ fraction $(r=$ $-0 \cdot 501, n=300)$ and with $10-2 \mu \mathrm{m}$ fraction $(r=0.565)$ are improved in comparison with those at the Lanzhou section. Again, the correlation with the clay $(<2 \mu \mathrm{m})$ content remains very low $(r=0 \cdot 133)$. It is also noticeable that the overall correlation coefficient between the magnetic susceptibility $(\chi)$ and carbonate concentration (percentage) is close to zero $(r=0 \cdot 012)$ and the first magnetic susceptibility peak corresponding to the S1S1 is absent here, although the frequency-dependent susceptibility $\left(\chi_{\mathrm{fd}}\right)$ does express the S1S1 well. According to the general correlation between the magnetic susceptibility $(\chi)$ and the frequency-dependent susceptibility $\left(\chi_{\mathrm{fd}}\right)$ at the nine chosen sections (Table I), the magnetic susceptibility peak expressing S1S1 should be present at this section. To examine possible reasons why it is absent, we made two predictions of the magnetic susceptibility $(\chi)$, the first based on the correlation between the $\chi$ and $\chi_{\mathrm{fd}}$ for the entire measured section $(r=0 \cdot 887)$, and the second on the linear relationship of the $\chi$ with the $>63 \mu \mathrm{m}$ fraction and $10-2 \mu \mathrm{m}$ fraction for the entire measured section. Both predictions indicate the existence of the $\chi$ peak corresponding to the S1S1. We noticed that the correlation coefficient between the carbonate concentration and the frequency-dependent susceptibility $\left(\chi_{\mathrm{fd}}\right)$ is negative in the lower $(2.5$ to $6 \mathrm{~m})$ portion $(r=-0.585)$ and positive in the upper $(0$ to $2.5 \mathrm{~m})$ portion $(r=0.415)$. We also noticed that the two major carbonate concentration highs in the lower portion (marked as III and II in Figure 4) correspond to two lows in both the susceptibility and the frequency-dependent susceptibility. However, the carbonate high at the upper portion (marked as I in Figure 4) is responsive to the frequency-dependent susceptibility high expressing the S1S1. We know that the frequency-dependent susceptibility is independent of the carbonate concentration and the susceptibility signature can be readily diluted by carbonate concentration. Therefore, the carbonate peak (marked as I in Figure 4) is responsible for the absence of the susceptibility peak expressing the S1S1.

Qinan section. At the Qinan section, the correlation coefficients of both the susceptibility $(\chi)$ and frequencydependent susceptibility $\left(\chi_{\mathrm{fd}}\right)$ with the $>63 \mu \mathrm{m}$ fraction (negative) and 10-2 $\mu \mathrm{m}$ fraction (positive) are very high (see Table I) and account for over 80 per cent of the variations in the magnetic susceptibility signatures. Unlike at the Lanzhou and Dingxi sections, the clay $(<2 \mu \mathrm{m})$ content is positively correlated with $\chi(r=0.491, n=250)$ and $\chi_{\mathrm{fd}}(r=0.615)$ at the Qinan section. Again, the carbonate concentration does not appear to correlate with the overall trend of the susceptibility $(r=-0.094)$, but the carbonate variations correspond very well with the 


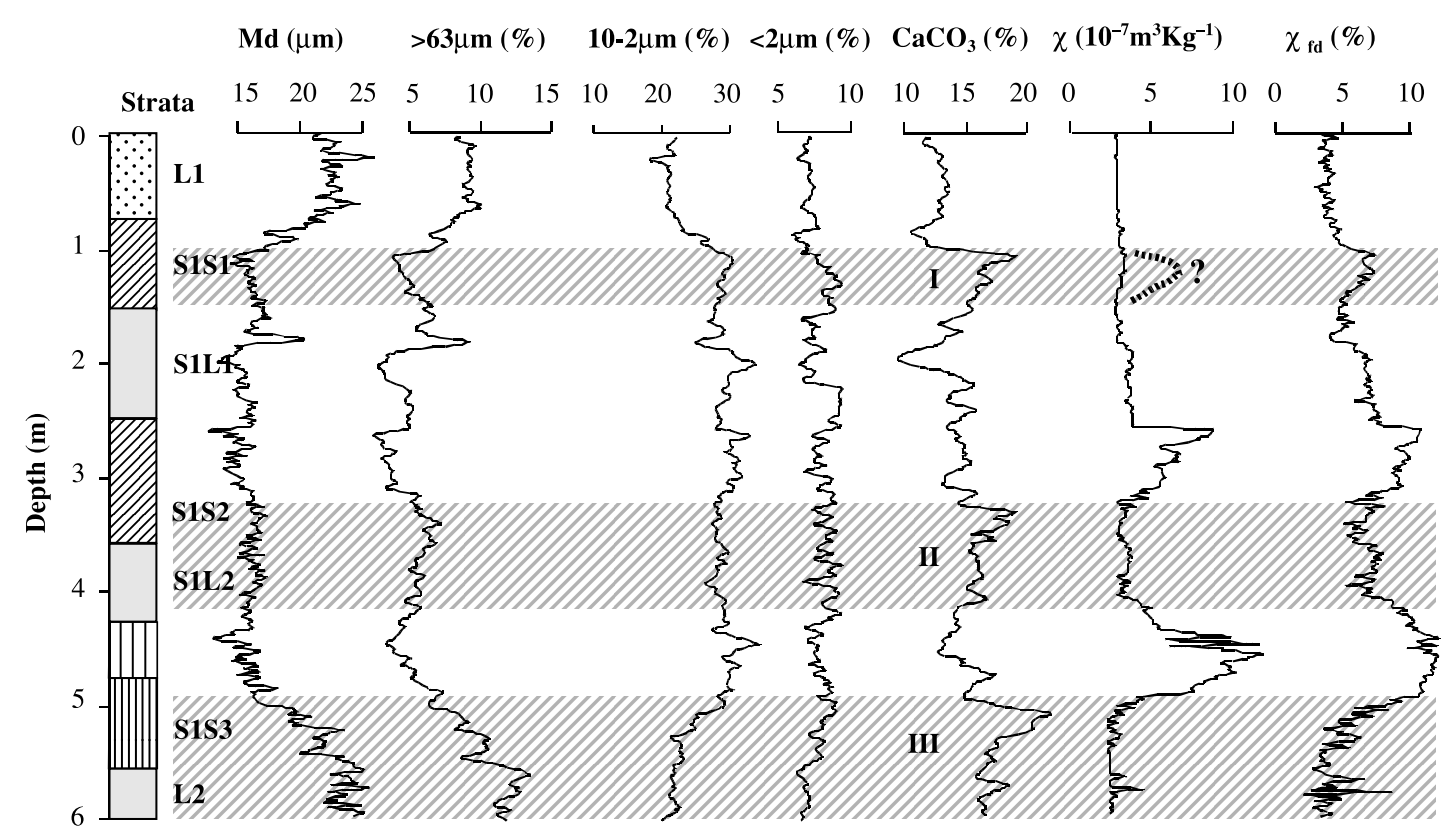

Figure 4. Dingxi section: field-observed pedostratigraphy and laboratory data. See Figure 3 caption for abbreviations

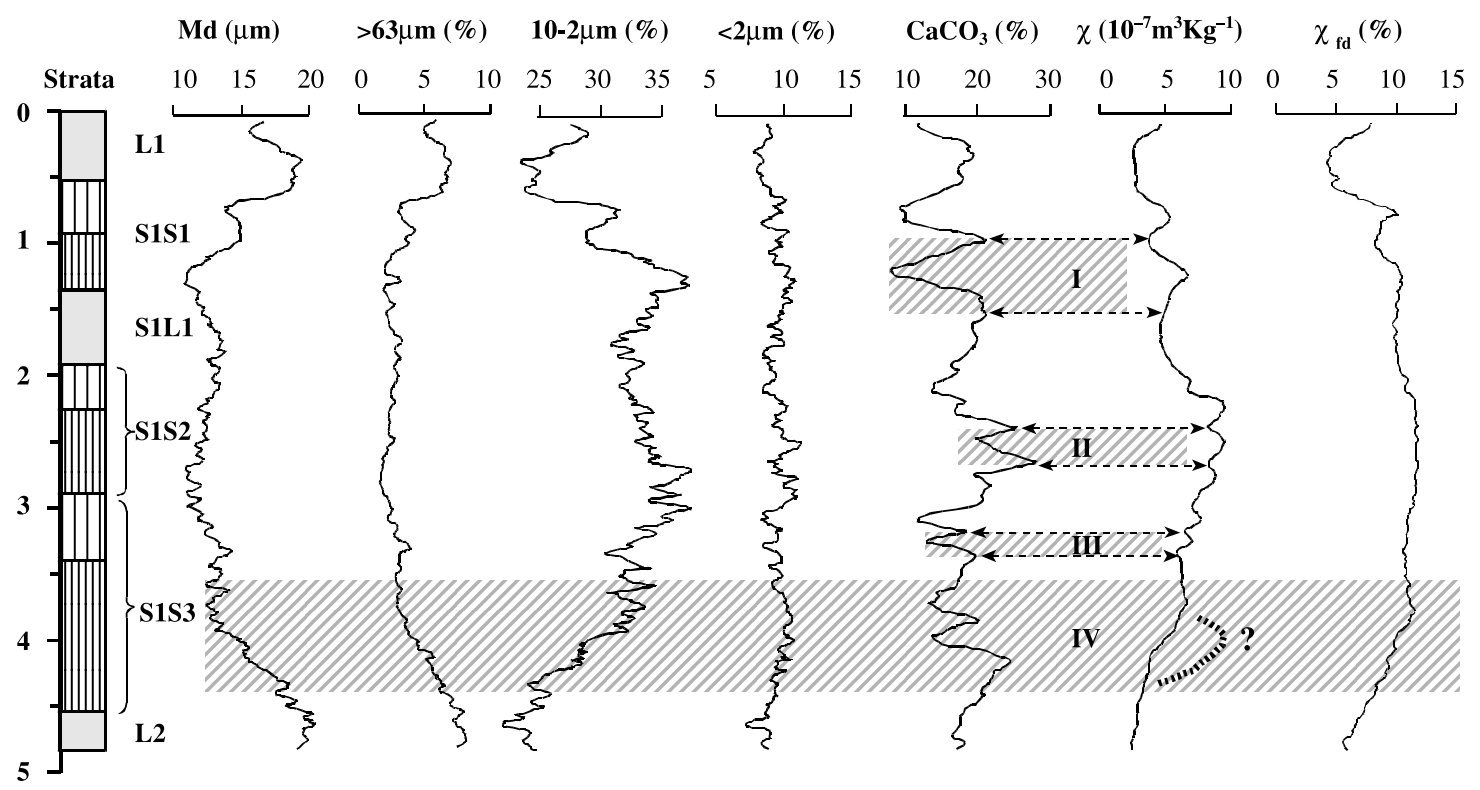

Figure 5. Qinan section: field-observed pedostratigraphy and laboratory data. See Figure 3 caption for abbreviations

secondary variations in the magnetic susceptibility as marked in Figure 5 (e.g., zones I, II, III, and IV). It is most noticeable that neither $\chi$ nor $\chi_{\mathrm{fd}}$ expresses the existence of the S1S3 unit although it is a much better developed palaeosol than the S1S2 and S1S1 according to the field observations (see Feng et al., 2004). It is apparent that the coarsening trend of the particle size in S1S3 has suppressed the susceptibility peak. The absence of the S1L2 between the S1S3 and S1S2 had the effect of making S1S3 even less distinguishable in the susceptibility curves. 


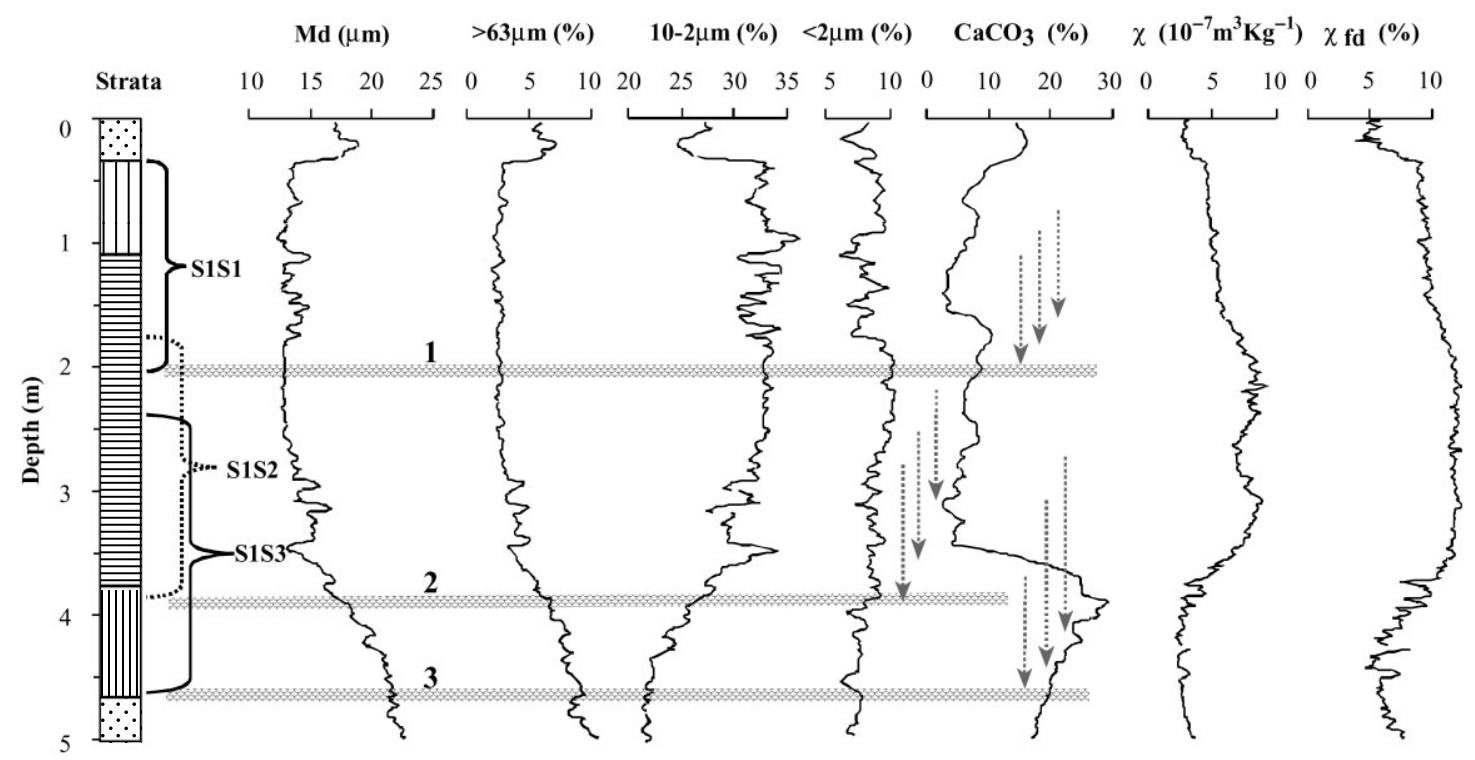

Figure 6. Tianshui section: field-observed pedostratigraphy and laboratory data. See Figure 3 caption for abbreviations

Tianshui section. The $\mathrm{S} 1$ is a pedocomplex at the Tianshui section, both S1L2 and S1L1 being absent (Figure 6). Carbonate concentration, as well as soil morphologic features (see Feng et al., 2004), suggest that the three palaeosols (S1S1, S1S2 and S1S3) are partially welded. That is, both the S1S3 and S1S2 palaeosol development formed the Bk horizon as indicated by arrows (associated with 3 and 2) in Figure 6 and shared a major portion of the soil profile. The carbonate-enriched layer 1 in Figure 6 may mark the bottom of the S1S1 or a later stage of the S1S1 carbonate leaching, and the S1S1 development might have annexed the uppermost portion of the S1S2 as the arrows indicate (associated with 1) in Figure 6. The soil annexation and welding not only altered S1L1 and S1L2 into soils but also altered the soil A horizons of the S1S3 and S1S2 into later B horizons, forming thick accretionary B horizons. As a result, the magnetic susceptibility signature does not distinguish the three soil-forming events (S1S1, S1S2, S1S3). The magnetic susceptibility $(\chi)$ is well correlated with the $>63 \mu \mathrm{m}$ fraction $(r=-0 \cdot 732, n=250)$, with the $10-2 \mu \mathrm{m}$ fraction $(r=0 \cdot 727)$ and with the carbonate concentration $(r=-0 \cdot 748)$. The clay content is also well correlated with the susceptibility $(r=0 \cdot 627)$.

Lantian section. In the Guangzhong Basin of the eastern part of the Chinese Loess Plateau, we investigated two similar sections: Baoji and Lantian. We focus here on the Lantian Section. The three soil-forming sequences observed in the more northwesterly sites (discussed above) occur as one single soil profile at the Lantian section. Two features are quite noticeable at this section. First, a major portion of the S1 palaeosol developed in a coarse parent material, suggesting that the palaeosol mainly developed in underlying older loess L2. Second, the carbonate concentration is quite low in the $\mathrm{Bt}$ and $\mathrm{BC}$ horizons and very high in the $\mathrm{Ck}$ horizon, implying that the $\mathrm{Ck}$ horizon might have served as the carbonate accumulation zone for all of the three soil-forming events (S1S1, S1S2, S1S3). The 10-2 $\mu \mathrm{m}$ fraction has the highest correlation coefficient with the magnetic susceptibility $(r=0.918, n=300)$, followed by the $>63 \mu \mathrm{m}$ fraction $(r=-0.886)$ and the $<2 \mu \mathrm{m}$ fraction $(r=0.793)$. The carbonate concentration plays almost no role in shaping the susceptibility curve $(r=0 \cdot 119)$ except in the Ck horizon. The particle-size coarsening from 2.5 to $4.5 \mathrm{~m}$ deep (shaded zone in Figure 7 ) is certainly responsible for lowering the susceptibility.

Qingyang section. In the centre of the eastern part of the Chinese Loess Plateau, two similar sections, Xunyi and Qingyang, are located in the same bioclimatic settings as the well-known Luochuan and Xifeng sections. Qingyang section is focused on here. It is characterized by a single thick soil profile with an A horizon, a $\mathrm{Bt}$ horizon and a Bk horizon (Figure 8). Not only are the correlation coefficients of the magnetic susceptibility $(\chi)$ 


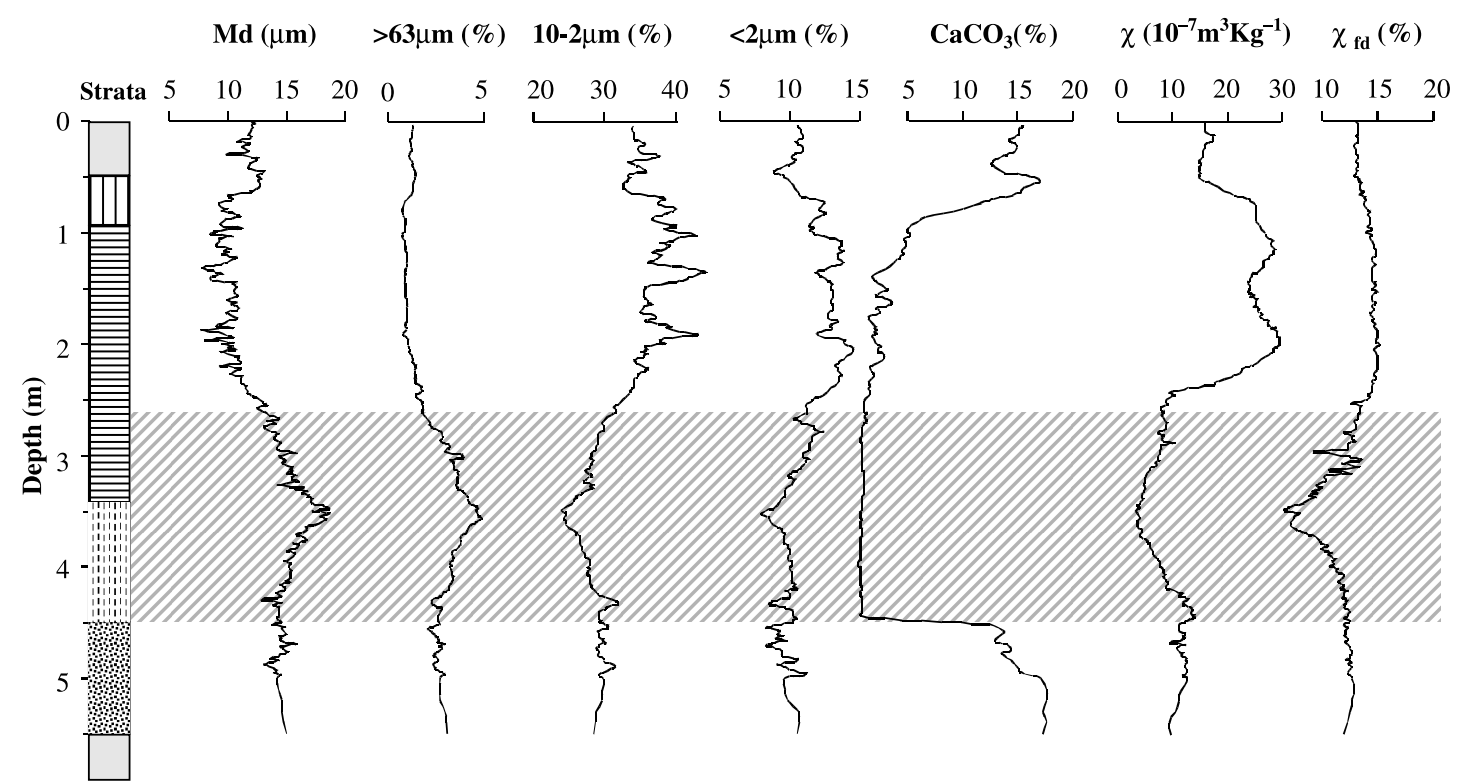

Figure 7. Lantian section: field-observed pedostratigraphy and laboratory data. See Figure 3 caption for abbreviations

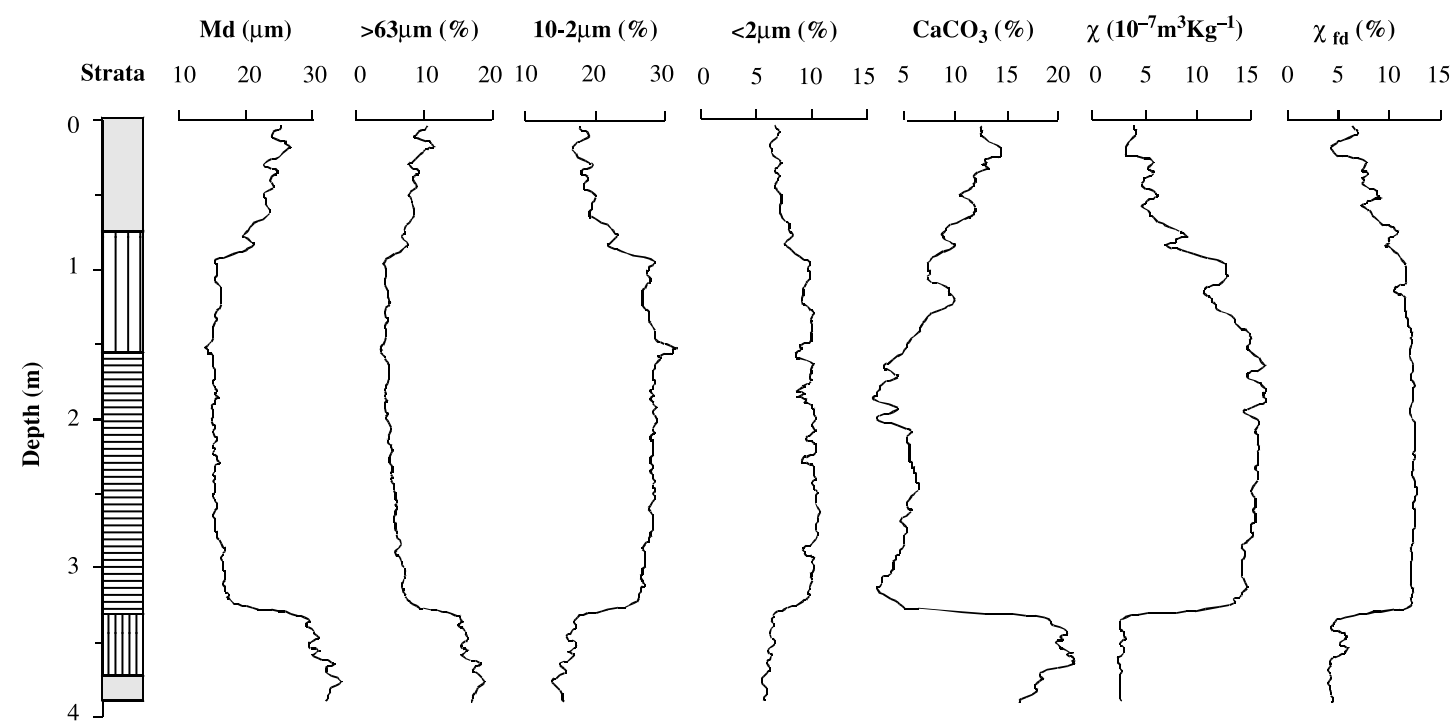

Figure 8. Qingyang section: field-observed pedostratigraphy and laboratory data. See Figure 3 caption for abbreviations

with the $>63 \mu \mathrm{m}$ fraction $(r=-0.838, n=200)$ and with the $10-2 \mu \mathrm{m}$ fraction $(r=0.967)$ very high, but the coefficients with the clay content $(r=0.955)$ and with the carbonate concentration $(r=-0.933)$ are also extremely high. It seems that none of the parameters, magnetic or non-magnetic, can distinguish the three soil-forming events (S1S1, S1S2, S1S3) within the S1 palaeosol.

Huanxian section. Farther to the northwest along the eastern transect, not only are the three constituent S1 palaeosols (S1S1, S1S2, S1S3) well preserved, but so are the intervening loess units (S1L1 and S1L2) (Figure 9). It seems that the $>63 \mu \mathrm{m}$ fraction shapes the overall trend of the magnetic susceptibility $(r=-0.853$, $n=350)$ and the carbonate concentration definitely modulates the secondary variations superimposed on the 


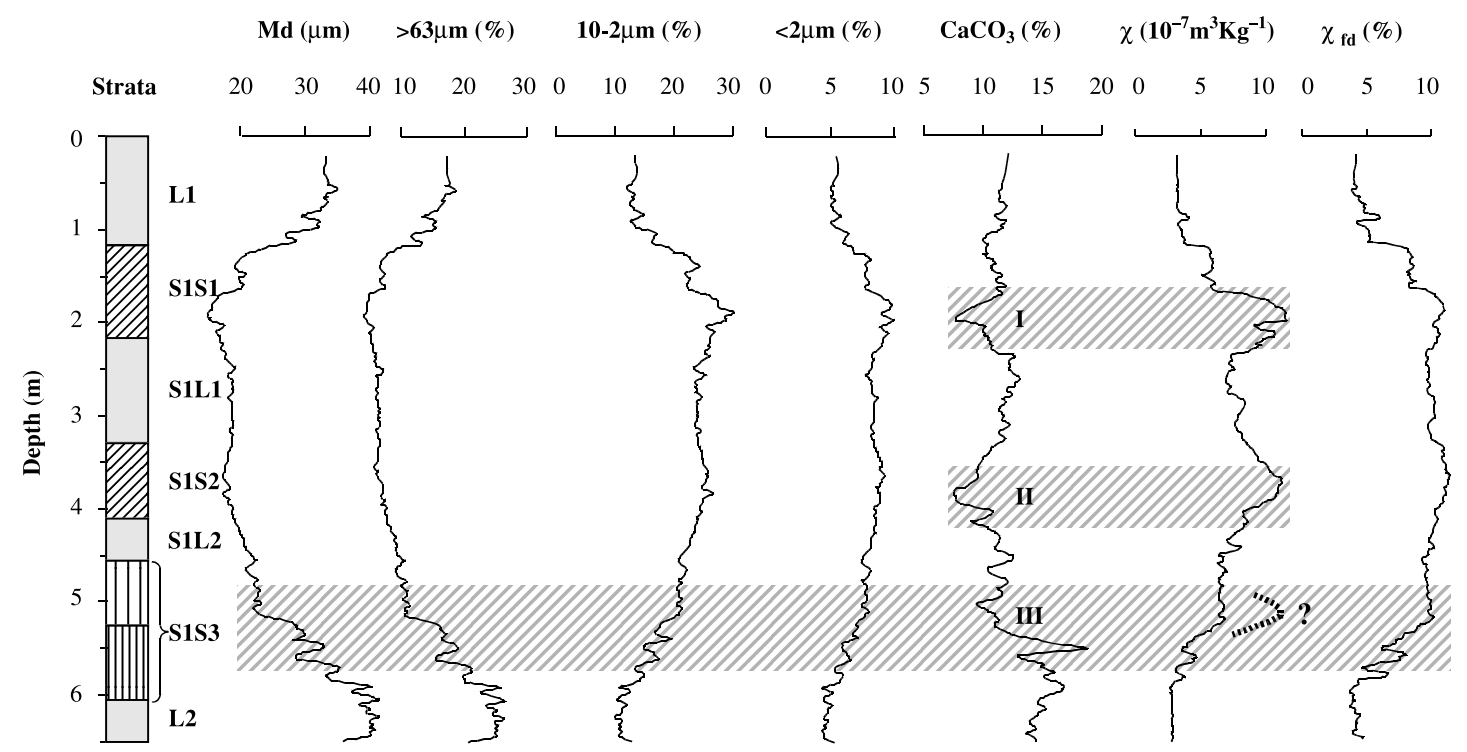

Figure 9. Huanxian section: field-observed pedostratigraphy and laboratory data. See Figure 3 caption for abbreviations

overall trend $(r=-0.733)$ as marked in Figure 9 (I and II). Again, the magnetic susceptibility does not express the existence of S1S3 although it is the best-developed palaeosol in this section. The magnetic susceptibility peak expressing S1S3 can be recovered by excluding the negative effect of the $>63 \mu \mathrm{m}$ fraction. In other words, the particle-size coarsening in zone III (Figure 9) should be held responsible for suppressing the magnetic susceptibility peak expressing the S1S3.

\section{DISCUSSIONS AND CONCLUSIONS}

Our analyses confirm that the $10-2 \mu \mathrm{m}$ fraction is a major contributor to the magnetic susceptibility signature, as reported by Han and Jiang (1999). If the so-called ultrafine superparamagnetic minerals are the ones that modulate the frequency-dependent susceptibility and the importance of the 10-2 $\mu \mathrm{m}$ fraction in contributing to both high- and low-frequency susceptibility is undeniable, well-weathered rinds of silt particles (several nanometres thick), as observed by Cui et al. (1994), Liu et al. (1995) and Maher and Thompson (2000), may be the answer to reconcile the discrepancy. That is, the ultrafine superparamagnetic minerals are primarily included in those weathered rinds of silt particles in the cases where the 10-2 $\mu \mathrm{m}$ fraction seems to be modulating both the magnetic susceptibility and frequency-dependent susceptibility signatures. Another possibility is that the ultrafine particles $(<0.03 \mu \mathrm{m})$ adhere to larger particles (e.g. $10-2 \mu \mathrm{m})$ so strongly that standard procedures failed to separate the particles (E. Derbyshire, 2003, personal communication). To examine the possible adherence of ultrafine particles to larger ones, we observed several representative samples under the microscope and the results show that the adherence of ultrafine particles to the larger ones mainly occurs in the clay fraction, not in the $10-2 \mu \mathrm{m}$ fraction.

It appears that the 10-2 $\mu \mathrm{m}$ fraction is the most important modulator (positive) which is in turn modulated primarily by the $>63 \mu \mathrm{m}$ fraction (negative). The clay content is a major player in shaping the magnetic susceptibility curves in the eastern part of the Chinese Loess Plateau and becomes an important player only in the southernmost section (e.g. at Tianshui) in the western part. Our explanation is that weathered magnetic rinds of silt-sized particles dominate the susceptibility signature in the sections where the weathering was relatively weaker during the last interglacial, whereas the weathering-produced magnetic clay-sized particles dominate the signature in the sections where the weathering was relatively strong. Clay translocation within the S1 palaeosol profiles, as indicated by field and X-ray diffraction observations of clay coatings on ped-faces in $\mathrm{Bt}$ and $\mathrm{Bk}$ horizons (Feng et al., 2003) and demonstrated by laboratory-analysed clay-content curves, must have moved 
some of the magnetic minerals downward so that the susceptibility only reflects the post-translocation distribution of the magnetic susceptibility-producing minerals. Also documented by this study, the best-developed palaeosol S1S3 at most of the sections studied is not expressed by the magnetic susceptibility at all because the S1S3 developed into underlying coarse loess (L2) and coarser texture lowers the susceptibility. Carbonate concentration is normally negatively correlated with the magnetic susceptibility for two reasons: (1) wellweathered and susceptibility-enhanced layers are normally carbonate-depleted (leached); and (2) the leached carbonate is normally accumulated in the layer immediately below the depleted layer. But carbonate can also accumulate in the susceptibility-enhanced weathered layer if carbonate leaching is not strong enough, such as in the upper portion (0-2.5 m) of the Dingxi section. In this case, the carbonate concentration simply suppresses the magnetic susceptibility peak. To conclude, extreme caution must be taken when one uses the susceptibility signature to retrieve a high-resolution proxy record of the last interglacial palaeoclimate in the Chinese Loess Plateau.

\section{ACKNOWLEDGEMENT}

This research is financially supported in part by a US National Science Foundation grant (BCS-0078557) and a Chinese Education Ministry grant (No. 2000-65).

\section{REFERENCES}

An Z, Kukla GJ, Porter SC, Xiao JL. 1991a. Late Quaternary dust flux on the Chinese Loess Plateau. Catena 18: $125-132$.

An ZS, Kukla GJ, Porter SC, Xiao JL. 1991b. Magnetic susceptibility evidence of monsoon variation on the Loess Plateau of central China during the last 130,000 years. Quaternary Research 36: 29-36.

Anderson RS, Hallet B. 1996. Simulating magnetic susceptibility profiles in loess as an aid in quantifying rates of dust deposition and pedogenic development. Quaternary Research 45: 1-16.

Banerjee SK, Hunt CP, Liu XM. 1993. Separation of local signal from regional paleomonsoon record of Chinese Loess Plateau: a rock magnetic approach. Geophysical Research Letters 20: 843-846.

Beer J, Shen CD, Heller F, Liu TS, Kubik PW. 1993. ${ }^{10}$ Be and magnetic susceptibility in Chinese loess. Geophysical Research Letters 20: 57-60.

Birkeland PW. 1999. Soils and Geomorphology (3rd edition). Oxford University Press: New York.

Buol SW, Hole FD, McCracken RJ. 1989. Soil Genesis and Classification. The Iowa State University Press: Ames, Iowa.

Catt JA. 1986. Soils and Quaternary Geology. Monographs on Soil and Resource Survey, No. 11. Clarendon Press: Oxford.

Catt JA. 1990. Paleopedology Manual. Quaternary International 6: 1-95.

Chen FH, Bloemendal J, Wang JM, Li JJ, Oldfield F. 1997. High resolution multi-proxy climate records from Chinese loess: evidence for rapid climatic changes over the last 75 kyr. Palaeogeography Palaeoclimatology Palaeoecology 130: 323-335.

Chen FH, Boemandel J, Feng Z-D, Wang JM, Gou ZG, Park E, Shi Q. 1999. East Asian monsoon variations during the Last Interglacial: evidence from the northwestern margin of the Chinese Loess Plateau. Quaternary Science Reviews 18: 1127-1135.

Cui YL, Verosub KL, Roberts AP. 1994. The effect of low-temperature oxidation on large multi-domain magnetite. Geophysical Research Letters 21: 757-760.

Derbyshire E, Keen DH, Kemp RA, Rolph TA, Shaw J, Meng XM. 1995. Loess-palaeosol sequences as recorders of palaeoclimatic variations during the last glacial interglacial cycle: some problems of correlation in north-central China. Quaternary Proceedings 4: 7-18.

Derbyshire E, Kemp KA, Meng XM. 1997. Climate change, loess and paloesols: proxy and resolution in North China. Journal of the Geological Society (London) 154: 793-805.

Derbyshire E, Meng XM, Kemp KA. 1998. Provenance, transport and characteristics of modern aeolian dust in western Gansu Province, China, and interpretation of the Quaternary loess record. Journal of Arid Environments 39: 497-516.

Evans ME, Heller F. 1994. Magnetic enhancement and paleoclimate: study of a loess/palaeosol couplet across the Loess Plateau of China. Geophysical Journal International 117: 257-264.

Evans ME, Heller F. 2001. Magnetism of loess/palaeosol sequences: recent developments. Earth Science Reviews 54: 129-144.

Evans ME, Rokosh CD. 2000. The last interglacial in the Chinese Loess Plateau: a petromagnetic investigation of samples from a northsouth transect. Quaternary International 68-71: 77-82.

Eyre JK, Shaw J. 1994. Magnetic enhancement of Chinese loess - the role of $\gamma \mathrm{Fe}_{2} \mathrm{O}_{3}$ ? Geophysical Journal International 117: $265-171$.

Fang XM, Ono Y, Fukusawa H, Pan BT, Li JJ, Guan DH, Oi K, Tsukamoto S, Torri M, Mishima T. 1999. Asian summer monsoon instability during the past 60,000 years: magnetic susceptibility and pedogenic evidence from the western Chinese Loess Plateau. Earth and Planetary Science Letters 168: 219-232.

Feng H, Pope GA, Feng Z-D, Cedfelli CE, Lanziotti A, Jones KW. 2003. Mineralogical and structural study of the S1 loess/palaeosol composition of the Chinese Loess Plateau using XRD and XANES based on Synchronton technologies. INQUA Conference, 23-31 June 2003, Reno, USA, abstract.

Feng Z-D. 1996. Climatic implications of magnetic susceptibility and ${ }^{10} \mathrm{Be}$ flux in Chinese loess. Catena 27: $143-147$.

Feng ZD. 1997. Geochemical characteristics of a loess-soil sequence in central Kansas, U.S.A. Soil Science Society of American Journal 61: 534-541.

Feng Z-D. 2001. Gobi dynamics in the northern Mongolian Plateau during the past 20,000+ years: preliminary result. Quaternary International 76/77: 77-83. 
Feng Z-D, Chen F-H. 1999. Problems of magnetic susceptibility signature as the proxy of the summer monsoon intensity in Chinese Loess Plateau. In International Symposium on Palaeosols and Climate Change, Chinese Science Bulletin 44 (suppl. 1): 97-104.

Feng, Z-D, Johnson WC. 1995. Factors affecting the magnetic susceptibility of a loess-soil sequence, Barton County, Kansas, USA. Catena 24: $25-37$.

Feng Z-D, Johnson WC, Diffendal RF. 1994a. Environment of eolian deposition in south-central Nebraska during the Last Glacial Maximum. Physical Geography 15(3): 250-258.

Feng Z-D, Johnson WC, Sprowl DR, Lu YC. 1994b. Loess accumulation and soil formation in central Kansas, USA, during the past 400,000 years. Earth Surface Processes and Landforms 19: 55-67.

Feng Z-D, Johnson WC, Sprowl DR, Lu YC, Ward PA. 1994c. Climatic signals from loess-soil sequences in the central Great Plains, USA. Palaeogeography Palaeoclimatology Palaeoecology 110: 345-358.

Feng ZD, Chen FH, Tang LY, Kang JC. 1998. East Asian monsoon variations and Gobi dynamics in marine isotope stages 4 and 3. Catena 33: 29-46.

Feng Z-D, Wang HB, Olson CG, Pope GA, Chen FH, Zhang JW, An CB. 2004. Chronological discord between the last interglacial palaeosol (S1) and its parent material in the Chinese Loess Plateau. Quaternary International 117: 17-26.

Fine P, Singer MJ, Verosub KL, TenPas J. 1993. New evidence for the origin of ferrimagnetic minerals in loess from China. Soil Science Society of American Journal 57: 1537-1542.

Fine P, Verosub KL, Singer ML. 1995. Pedogenic and lithogenic contribution to the magnetic susceptibility record of the Chinese loess/ palaeosol sequence. Geophysical Journal International 122: 97-107.

Foth HD. 1978. Fundamentals of Soil Science (6th edition). John Wiley and Sons: New York.

Han J-M, Jiang W-Y. 1999. Particle size contribution to bulk magnetic susceptibility in Chinese loess and palaeosol. Quaternary International 62: 103-110.

Heller F, Evans ME. 1995. Loess magnetism. Reviews of Geophysics. 33: 211-240.

Heller F, Liu TS. 1986. Paleoclimatic and sedimentary history from magnetic susceptibility of loess in China. Geophysical Research Letters 13: $613-618$

Heller F, Shen CD, Beer J, Liu XM, Liu TS, Bronger A, Suter M, Bonani G. 1993. Quantitative estimates of pedogenic ferromagnetic mineral formation in Chinese loess and paleoclimatic implications. Earth and Planetary Science Letters 114: 385-390.

Janitzky, P. 1987. Particle size analysis. In Field and Laboratory Procedures used in Soil Chronosequence Study, Singer M, Janitzky P (eds). US Geological Survey Bulletin 1648. Government Printing Office: Washington, DC; 11-16.

Kemp RA, Derbyshire E, Meng X-M, Chen F-H, Pan B-T. 1995. Pedosedimentary reconstruction of a thick loess-paloesol sequence near Lanzhou in North-Central China. Quaternary Research 43: 30-45.

Kemp RA, Derbyshire E, Meng X-M. 1997. Micromorphological variations of the S1 palaeosol across northwest China. Catena 31: 7790.

Kukla G, Heller F, Liu XM, Xu TC, Liu TS, An ZS. 1988. Pleistocene climates in China dated by magnetic susceptibility. Geology 16: $811-814$.

Kukla G, An ZS, Melice JL, Gavin J, Xiao J-L. 1990. Magnetic susceptibility record of Chinese loess. Transactions of the Royal Society of Edinburgh (Earth Sciences) 81: 263-288.

Li, JJ, Feng Z-D, Tang LY. 1988. Late Quaternary monsoon patterns on the Loess Plateau of China. Earth Surface Processes and Landforms 13: $125-135$.

Li Z, Zhou SK, Zeng DW. 1996. Relation between magnetic susceptibility and $\mathrm{Fe}^{2+} /\left(\mathrm{Fe}^{2+}+\mathrm{Fe}^{3+}\right)$ and relative contents of iron in Zhouyuan loess. Marine Geology and Quaternary Geology 16(4): 105-112 (in Chinese).

Liu J. 2000. Reductive diagenesis of magnetic minerals: a review. Marine Geology and Quaternary Geology 20(4): 103-107 (in Chinese).

Liu XM, Liu TS. 1993. Magnetic mineral characteristics of Chinese loess and its paleoclimatic significance. Quaternary Sciences 3: 281287 (in Chinese).

Liu XM, Shaw J, Liu TS, Heller F, Yuan BY. 1992. Magnetic mineralogy of Chinese Loess and its significance. Geophysical Journal International 108: 301-308.

Liu XM, Rolph T, Bloemendal J, 1995. The Citrate-Biicarbonate-Dithionite (CBD) removable magnetic component of Chinese loess. Quaternary Proceedings 4: 53-58.

Liu X-M, Hess P, Rolph T, Beget JE. 1999. Properties of magnetic mineralogy of Alaskan loess: evidence for pedogenesis. Quaternary International 62: 93-102.

Machette M. 1986. Calcium and magnesium carbonates. In Field and Laboratory Procedures used in a Soil Chronosequence Study, Singer MJ, Janitzky P (eds). US Geological Survey Bulletin 1648. US Government Printing Office: Washington, DC; 30-33.

Maher BA. 1998. Magnetic properties of modern soils and Quaternary loessic palaeosols: paleoclimatic implications. Palaeogeography Palaeoclimatology Palaeoecology 137: 25-54.

Maher BA. 1999. Comments on: origin of the magnetic susceptibility singanal in Chinese loess. Quaternary Science Reviews 18: 865869.

Maher BA, Thompson R. 1991. Mineral magnetic records of the Chinese loess and palaeosols. Geology 19: 3-6.

Maher BA, Thompson R. 1992. Paleoclimatic significance of the mineral magnetic records of the Chinese loess and palaeosols. Quaternary Research 37: 155-170.

Maher BA, Thompson R. 1995. Paleorainfall reconstructions from pedogenic magnetic susceptibility variation in the Chinese loess and palaeosols. Quaternary Research 44: 383-391.

Maher BA, Thompson R. 2000. Palaeomonsoons I: the magnetic record of palaeoclimate in the terrestrial loess and palaeosol sequence. In Quaternary Climates, Environments and Magnetism, Maher BA, Thompson R (eds). Cambridge University Press: New York; 83-125.

Maher BA, Thompson R, Zhou LP. 1994. Spatial and temporal reconstruction of changes in the Asian palaeomonsoon: a new mineral magnetic approach. Earth and Planetary Science Letters 125: 461-471.

Meng XM, Derbyshire E, Kemp RA. 1997. Origin of the magnetic susceptibility singanal in Chinese loess. Quaternary Science Reviews 16: $833-839$.

Meng XM, Derbyshire E, Kemp RA. 1999. Reply to comments on: origin of the magnetic susceptibility singanal in Chinese loess. Quaternary Science Reviews 18: 871-875. 
Mullins CE. 1977. Magnetic susceptibility of the soil and its significance in soil science - A review. Journal of Soil Sciences 28: $223-246$.

Rokosh CD, Rutter NW, Ding Z, Sun J. 2002. Regional lithofacies and pedofacies variations along a north-south climatic gradient during the Last Glacial period in the central Loess Plateau, China. Quaternary Science Reviews 21: 811-817.

Shen CD, Beer J, Liu TS, Oeschger H, Bonani G, Suter M, Wolfli W. 1992. ${ }^{10}$ Be in Chinese loess. Earth and Planetary Science Letters 109: $169-177$.

Sun DH, Zhou J, Jiang WC, Porter SC. 1995. Last interglacial summer monsoon reconstruction in the Chinese Loess Plateau. Chinese Science Bulletin 40(20): 1873-1875 (in Chinese).

Sun, JM, Liu TS. 2000. Multiple origins and interpretations of the magnetic susceptibility signal in Chinese wind-blown sediments. Earth and Planetary Science Letters 180: 287-296.

Thompson R, Oldfield F. 1986. Environmental Magnetism. Allen and Oldwin: London.

Verosub LK, Fine P, Singer MJ, TenPass J. 1993. Pedogenesis and paleoclimate: interpretation of the magnetic susceptibility record of Chinese loess-palaeosol sequences. Geology 21: 1011-1014.

Virina EI, Faustov SS, Heller E. 2000. Magnetism of loess-palaeosol formation in relation to soil-forming and sedimentary processes. Physics and Chemistry of the Earth 25(5): 475-478.

Wang J, Liu ZC, Jiang WY, Dong LX, Zhu MZ, Gao F. 1996. A relationship between the magnetic susceptibility and grain size and minerals, and their paleo-environmental implications. Acta Geographica Sinica 15(2): 155-163 (in Chinese).

William M. 1992. Evidence for the dissolution of magnetite in recent Scottish peat. Quaternary Research 37: 171-182.

Zhang ZG, Chen Y. 1995. New development in the loess in China. Episodes 18: 58-60.

Zheng HB, Oldfield F, Yu LZ, Shaw J, An ZS. 1991. The magnetic properties of particle-sized samples from the Luo Chuan loess section: evidence for pedogenesis. Physics of the Earth and Planetary Interiors 68: 250-258.

Zhou LP, Oldfield F, Wintle AG, Robinson SG, Wang JT. 1990. Partly pedogenic origin of magnetic variations in Chinese loess. Nature 346: $1-3$.

Zhu R, Deng C, Jackson MJ. 2001. A magnetic investigation along a NW-SE transect of the Chinese Loess Plateau and its implications. Physics and Chemistry of the Earth 26(11-12): 867-872. 